УДК $930.2: 63$ - 051(477.41) 1791/1800

\title{
ГЕНЕАЛОГІЯ СЕЛЯНСЬКИХ РОДИН С. ТЕРНІВКА ЧЕРКАСЬКОГО ПОВІТУ КИЇВСЬКОЇ ГУБЕРНІЇ ЗА МАТЕРІАЛАМИ РЕВІЗІЙНИХ ПЕРЕПИСІВ КІНЦЯ ХVIII - СЕРЕДИНИ ХІХ СТ.
}

\section{Петрова Інна}

Статтю присвячено дослідженню генеалогії селянських родин с. Тернівка Черкаського повіту Київської губернії. Як основні джерела для упорядкування родоводів селянських родин було обрано ревізькі «сказки», щчо зберігаються у Державному архіві Київської області. У статті конкретизовано час створення ревізьких «сказок» селянських родин с. Тернівка Черкаського повіту Київської губернії, з'ясовано сучасний стан їхнього збереження, виявлено інформаційний потенціал документів. Ревізькі «сказки» допомогли встановити динаміку чисельності, природного руху, статево-вікової структури селян Тернівки за 1795-1834 рр. У статті розглянуто в часовому вимірі співвідношення між чоловіками та жінками, демографічне навантаження на працездатне населення, тривалість життя селян цісї локальноі території. Також було досліджено історію родин (Лихочасів, Третяків, Бугер), родинні зв'язки між ними та відносини. Визначено головні атрибути особи - ім'я, прізвище, вік, місце проживання, що фігурують у матеріалах ревізійних переписів. Авторка дослідження обтрунтувала необхідність використання інших джерел (метричних книг, сповідальних відомостей, матеріалів військового обліку та наборів тощчо) для реконструкиії родоводу селян. Комплексно подана в статті інформація зацікавить музейних працівників, архівістів, істориків-аматорів.

Ключові слова: джерелознавчий аналіз, генеалогія, ревізія, ревізькі «сказки», Тернівка, Київська губернія.

У другій половині XVIII - на початку XIX ст. під впливом політичних чинників (інкорпорації українських земель до складу Російської імперії, уніфікації нормативно-правової бази до російського законодавства) відбуваються кардинальні зрушення в соціальній стратифікації українського суспільства. У 1783 р. на Лівобережжі та в Слобідській Україні запроваджується кріпосне право, надалі оформлюються станові права і привілеї дворянства (Жалувана грамота дворянства 1785 р. поширюється на українське шляхетство і верхівку старшини), ще раніше, у 1765 р., спостерігається перетворення козаків-компанійців, підпомічників, козацьких родичів та підсусідків на військових обивателів (далі триває поступова трансформація останніх до категорії державних селян). Дослідження соціально-правових змін у структурі соціальних спільнот у цей період не можливе без урахування їх генетично-родової тяглості, витвореної поколіннями членів цієї групи. Саме тому вивчення історії соціальних спільнот (власницьких та державних селян, священників, міщан, дворян) крізь призму генеалогічних зв'язків набуває належної наукової актуальності. Найчастіше 3 метою дослідження історії малих популяцій і територій, зокрема родоводу селян, залучають метричні книги, сповідальні відомості, ревізькі «сказки», справи про розірвання шлюбу, 
накладання єпитимії тощо. Основним джерелом для визначення чисельності, статево-вікової структури населення, родоводу селян села Тернівки є ревізькі «сказки» 1795, 1811, 1816, 1834 рр.

Первинні документи ревізького обліку населення Російської імперії (ревізькі «сказки») перебували в центрі уваги російських та українських дослідників В. Кабузана [5; 6, 128-140], О. Дружиніної [3], Г. Махнової [12, 111-116], О. Под’япольської [14, 310-321], А. Гедьо [2, 551-562], В. Ликової [9, 345-351], А. Рашина [16], Г. Орлової [13, 71-82], І. Троїцької [22], М. Маркової [11] та ін. До матеріалів ревізійних переписів як джерела генеалогічних досліджень селянських родоводів зверталися Ю. Легун [8], О. Петренко [7], Н. Лобко [10, 132-146] та ін.

Метою нашої статті $є$ вивчення демографічної ситуації села Тернівки Черкаського повіту Київської губернії за 1795-1834 рр., а також реконструкція родинного середовища за матеріалами ревізьких «сказок» 1795-1834 pp.

Село Тернівка Смілянського району Черкаської області лежить по обидва боки річки Гнилий Ташлик. На жаль, на сьогодні збереглося достатньо мало інформації щодо історії населеного пункту. Про Тернівку згадує у своєму дослідженні Л. Похилевич. У «Сказании о населенных местностях Киевской губернии» (1864) він пише: «Село Тернівка розташоване уздовж річки Ташлик нижче від села Попівки, від якого відділяється тільки невеликим яром. Село Смілянка лежить іще нижче вздовж Ташлику за 3 версти. Жителів обох статей - 859. Землі в окружній межі - 1809 десятин. Поблизу села є могили й викопують черепки якихось посудин з нерозбірливими літерами. Один з таких черепків зберігається в церкві. Село належить генерал-майору Владиславу й підпоручику Олександру Християновичам Гревсам, батько яких купив цей маєток у графа Самойлова. Церква Дмитрівська, дерев’яна, 7-го класу; землі має 38 десятин; побудована 1822 року невеликим коштом покійного батька власників генерал-майора Християна Гревса [дерев’яна церква Дмитра Солунського - I. П.]» [15, 512]. Також $\epsilon$ згадки про цей населений пункт в «Історії міст і сіл Української РСР. Черкаська область» $[4,516]$.

Основними демографічними показниками, що характеризують стан і якісний склад населення локальної території (у нашому випадку - села Тернівки), $\epsilon$ чисельність, статево-вікова й етнічна структура, народжуваність, смертність, природний та механічний приріст населення тощо. Розглядаючи демографічні процеси серед власницьких селян Тернівки за ревізькими «сказками», необхідно зазначити, що протягом 1795-1834 рр. чисельність цієї соціальної групи неухильно зростала. Якщо в 1795 р. в населеному пункті мешкало 578 селян, у 1816 р. - 631, то в 1834 р. - 747 осіб. Найбільші темпи приросту населення в Тернівці спостерігалися протягом 1816-1834 рр. Наприклад, чисельність селян 
зросла на 116 осіб (або на 18,4 \%, порівнюючи з попереднім періодом). Найнижчі темпи приросту населення було зафіксовано у 1795-1816 рр. У цей період загальна кількість селян Тернівки збільшилася лише на 53 особи, або на 9,1\%. Основними причинами, що гальмували темпи приросту населення, були різке зменшення показників народжуваності та збільшення смертності внаслідок поширення різних захворювань.

Протягом 1796-1811 pр. серед категорії селян чоловічої статі села Тернівки був зареєстрований 71 летальний випадок. Найвищі показники смертності відображають ревізькі «сказки» в 1798 р. - 12 осіб та в 1799 р. - 9 осіб (див. рис. 1. - І. П.). Упродовж 1811-1815 рр. було зафіксовано 39 випадків смерті серед чоловіків. Найбільші показники смертності становили в 1813 р. - 13 випадків. Матеріали VI ревізії засвідчують, що найбільш вразливою категорією населення були діти до одного року. Зокрема, серед осіб, народжених 1810 р., вмерли: у 1811 p. - 1 особа, у 1812 p. - 3 особи, у 1813 p. - 1 особа, у 1814 p. 1 особа, у 1815 р. - 4 особи. Тобто з 39 померлих осіб чоловічої статі 19 осіб становили діти та підлітки до 16 років (або 48,7 \% від усієї кількості померлих).

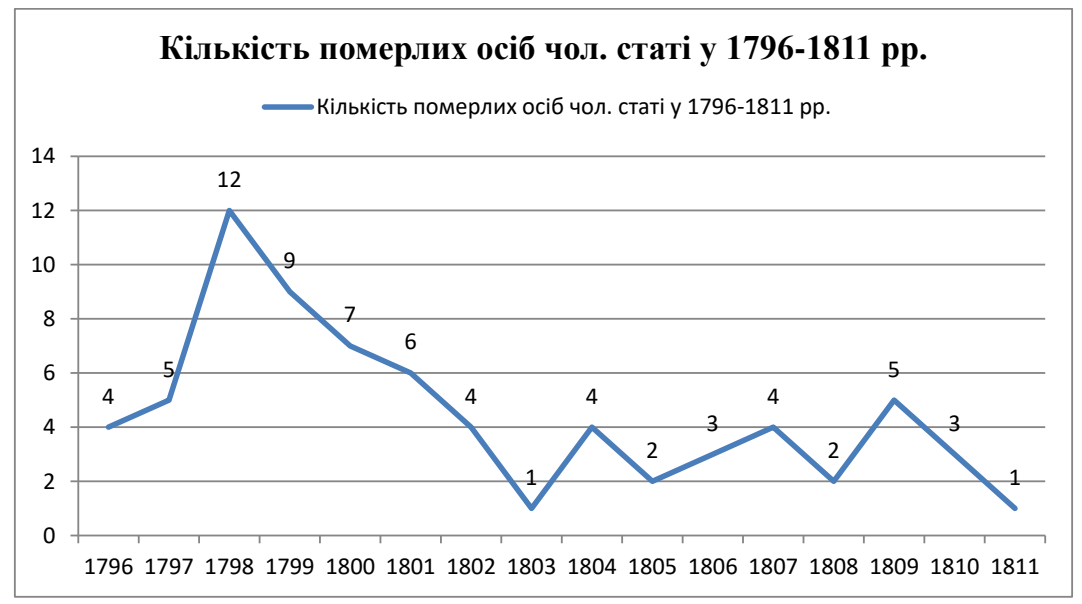

Рис. 1. Динаміка смертності серед селян села Тернівки (1796-1811 рр., о. ч. с.)

Упродовж 1816-1834 pр. померло 105 осіб чоловічої статі (втрати становили 32,23 \% від загальної чисельності осіб чоловічої статі), з яких 21 особа були дітьми та підлітками до 16 років (див. рис. 2. - І. П.). Причому піковими періодами втрат стали 1816, 1817, 1826 та 1831 рр. 3 кількістю померлих у 10, 12, 8 і 8 осіб чоловічої статі відповідно. Найбільші показники смертності становили в 1817 p. - 12 випадків. Серед причин, що призводили до втрат серед місцевого 
населення, були зростання випадків інфекційних захворювань, фізичних травм, перинатальних смертей.

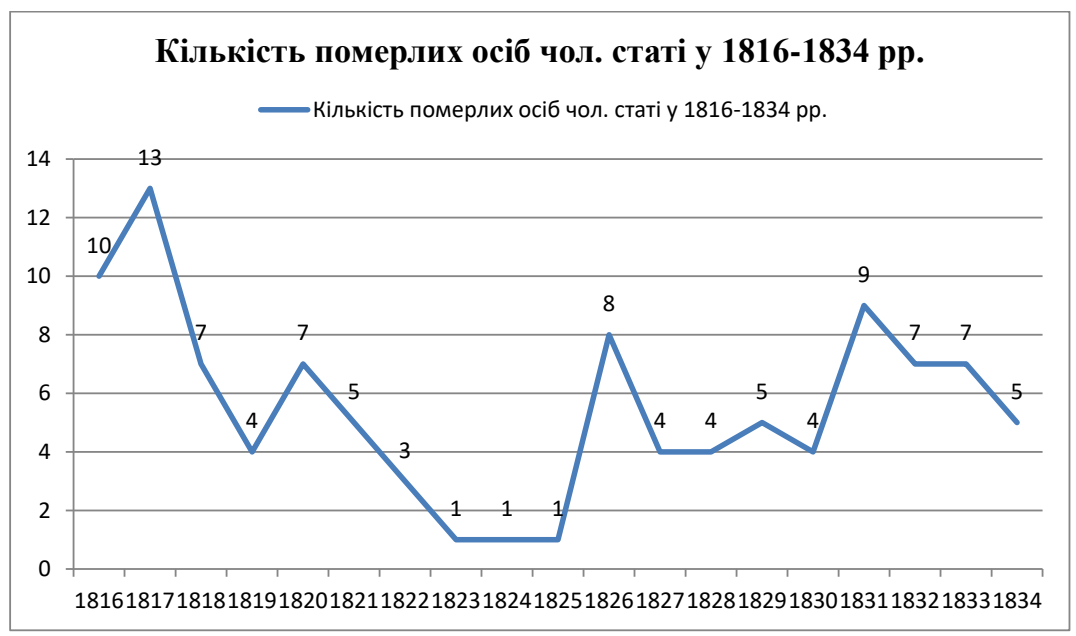

Рис. 2. Динаміка смертності серед селян села Тернівки (1816-1834 pp., о. ч. с.)

На динаміку чисельності населення села впливало збільшення випадків втеч. Між V та VI ревізіями Тернівку залишила 31 особа (15 осіб чоловічої та 16 осіб жіночої статі). Втечі здебільшого були поодинокі, хоча ревізії зафіксували також масові випадки. Так, наприклад, Василь Петрович Лихочас у 1811 р. у віці 56 років втік із села (його син Василь втік іще раніше - у 1809 р.). Обидва повернулися до рідного села. У 1812 р. повернувся Василь Петрович і наступного року помер. Син Василь з'явився в селі у 1814 р. У Василя Тихоновича Мирошника мати Євгенія Гаврилівна (в оригіналі - Свгенія Гаврилова) втекла 1813 р., а іiї онука Катерина - у 1815 р. [19, 601]. У 1813 р. втекла ціла родина - Михайло Петрович Белянський, його дружина Авдотья, діти Єлисей, Дар'я та Акулина [19, 618 зв. - 619]. У 1803 р. (так у ревізії) втекли дві племінниці Афанасія Івановича Ремеза - Ганна та Устинья [19, 619]. За міжревізійний період (18161834 рр.) чисельність осіб, які самовільно залишили Тернівку, становила 12 осіб чоловічої та 8 осіб жіночої статі. Причому в 1817 р. втекли відразу 36-річна мати Наталія і 20-річна сестра Марія померлого того ж року Опанаса Григоровича Яценка [20, 67].

Найчастіше втікачів повертали до їхніх колишніх власників (або вони самостійно поверталися), після цього особи чоловічої статі здебільшого потрапляли до складу рекрутських партій. Це пояснювалось особливостями проведення й організації призовних компаній у той період - набір рекрутів 3 власницьких се- 
лян повністю залежав від волі поміщика. Саме втікачами землевласники намагалися виконати норми рекрутського набору. Так, наприклад, Максим Корнійович Надгребельний втік з Тернівки 1801 р. у 15 років. У 1812 р. він повернувся додому й одразу був відданий у рекрути [19, 616 зв.]. Так само вчинили 3 Данилом Михайловичем Слободяником, який у віці 35 років втік у 1811 р. $з$ Тернівки (ще раніше, у 1810 р., село залишив його рідний брат Василь, коли йому виповнилося 25 років). У 1813 р. Данило Михайлович Слободяник повернувся додому, тоді ж його внесли до складу рекрутської партії. Можливо, уникаючи такої долі, Василь Михайлович Слободяник у 1815 р. повернувся додому і тоді ж залишив село [19, 617 зв.]. Аналогічно зробили з Екимом (Юхимом) Федоровичем Кранцеусом, який втік 1809 р., а повернувся 1813 р. Того ж року його віддали в рекрути [19, 620 зв.]. Рекрутська доля чекала також на Кіндрата Олексійовича Наконечного, який у віці 33 років втік у 1811 р. $з$ села і того ж року повернувся. Його віддали в рекрути 1813 р. [19, 622]. У 1815 р. повернувся до Тернівки Герасим Гнатович Казенний, у 1816 р. його віддали в рекрути [19, 624 зв.]. Протягом 1796-1811 pр. із Тернівки до складу рекрутських партій було зараховано 21 особу. У міжревізійний період найбільша кількість осіб, яка поповнила лави рекрутів із села Тернівки в 1806 р., - 7 осіб (під час чергової російсько-турецької війни 1806-1812 рр.). У міжревізійний період (VI та VII ревізії) в рекрути чи козаки було віддано 19 осіб, пік рекрутчини припав на розпал Вітчизняної війни 1812 р. У 1812-1813 pр. було рекрутовано 16 осіб. Вік рекрутів був різним, двом особам виповнилося 19 років, одній - 20 років, двом -21 рік, одній - 22 роки, двом - 23 роки, двом - 24 роки, двом - 25 років, одній - 26 років, одній -27 років, одній - 29 років, одній - 30 років, двом - 35 років, одній - 37 років. За 1816-1834 рр. лави рекрутів поповнили 15 жителів Тернівки (або 4,5\% від усього чоловічого населення села).

Оскільки первинний облік - ревізькі «сказки» V (1794-1808 pp.) та VII (18151826 рр.) ревізій - фіксував інформацію про осіб жіночої статі, то за допомогою цих документів можна реконструювати статево-вікову структуру поміщицьких селян Тернівки. Вона формується під спільним впливом трьох факторів: співвідношення кількості народжених живими хлопчиків і дівчаток, вікової диференціації смертності у чоловіків і жінок, статево-вікового складу мігрантів. Статевовікова піраміда показує динамічний розвиток соціальної верстви селян Київщини на прикладі Тернівки та досить збалансовану статево-вікову структуру місцевого соціуму на час проведення ревізії. Молодь і діти становили переважну більшість жителів села (див. рис. 3. - І. П.). Виходячи з даних статево-вікової піраміди, майже ідентичним у 1795 р. є співвідношення осіб чоловічої та жіночої статі у вікових категоріях 0-4, 5-9, 15-19, 35-39, 45-49, 55-59 років; значне 
перевищення кількості осіб жіночої статі над чоловіками спостерігається в категоріях 20-24 років (на 12 осіб кількість жінок перевищує кількість чоловіків удвічі), 25-29 років (на 11 осіб або на 44 \%), 50-54 років (на 7 осіб); перевищення кількості осіб чоловічої статі над особами жіночої статі спостерігається в категоріях 10-14 років (на 17 осіб або на 42,5\%), 30-34 років (на 8 осіб або на $47 \%$ ), 40-44 років (на 4 особи або на 33\%), 60-64 (на 3 особи або більше, ніж удвічі), 70-79 років (на 3 особи або в три рази більше, ніж жінок), а в категоріях 65-69 та 80 і більше років за відсутності жінок взагалі чоловіків було в два рази більше (на 2 особи в кожній віковій категоріі).

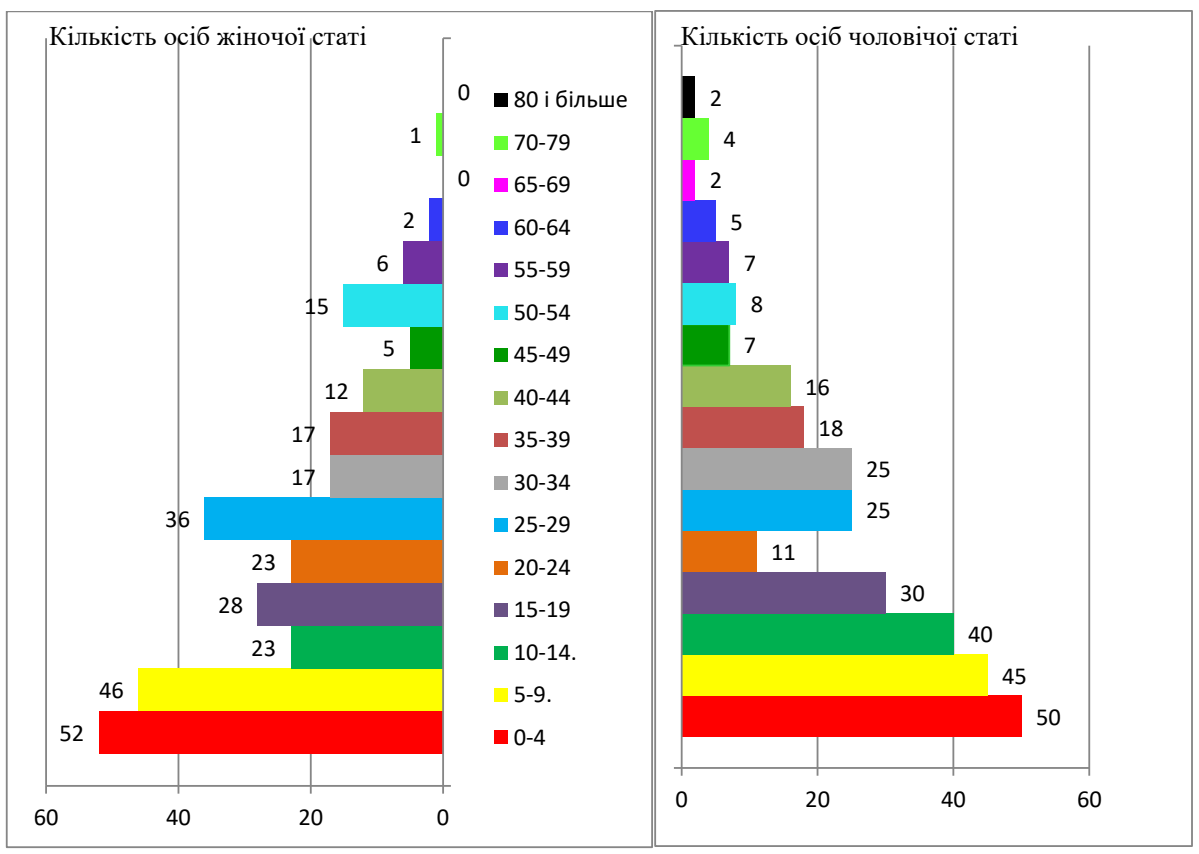

Рис. 3. Статево-вікова піраміда селян Тернівки за матеріалами V ревізії (1795р.)

Статево-вікова піраміда селян за матеріалами VII ревізії знову ілюструє динамічний розвиток населення Тернівки. Діаграма засвідчує домінування в статево-віковій структурі населення вікової категорії дітей та молоді (див. рис. 4. - І. П.). Цікаво, що немовлят та малечі обох статей до 5 років нараховувалося по 50 осіб. Також паритет спостерігався у віковій категорії 55-59 років по 4 особи обох статей. У вікових категоріях 5-9, 10-14, 15-19, 25-29, 30-34, 40-44, 45-49, 70-79 років домінували жінки. У вікових категоріях 20-24, 35-39, $50-54,60-64,60-69,80$ і більше років спостерігалося домінування чоловічої статі. Загалом жінок було на 39 осіб більше, ніж чоловіків. 


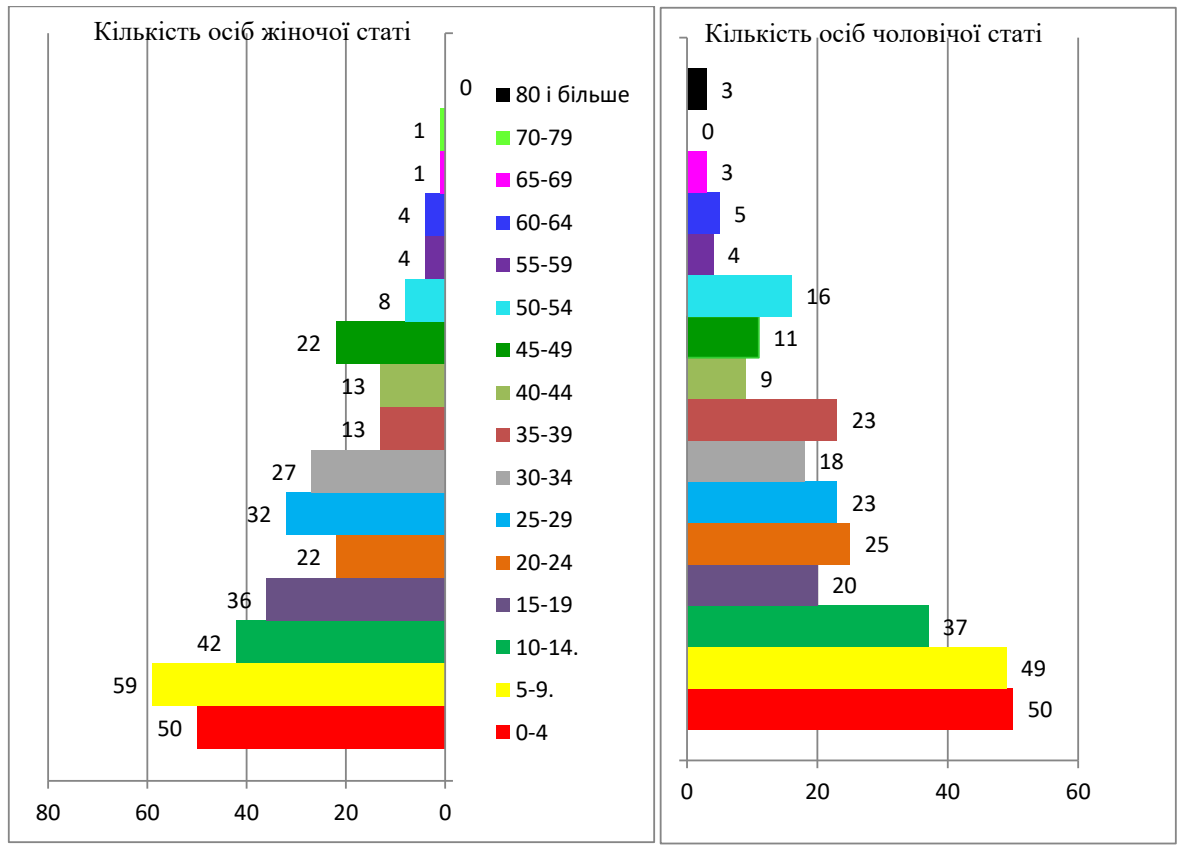

Рис. 4. Статево-вікова піраміда селян Тернівки за матеріалами VII ревізії (1816 р.)

Під час аналізу матеріалів ревізьких «сказок» 1795 та 1816 рр. нами було виявлено велику кількість осіб, вік яких закінчувався на «5» чи «0» (так званих ювілярів). На такий недолік переписів у Російській імперії (неточне відображення віку - І. П.) неодноразово звертав увагу полтавський дослідник Ю. Волошин $[1,6]$. Виникали сумніви щодо відповідності статистичних записів реальному біологічному вікові людей і в І. Сердюка, який вважав, що частка ювілярів повинна перебувати в межах $9 \%$. Однак підрахунки дослідника вказували на перевищення цієї норми втричі. Учений дійшов висновку, що оскільки головною подією в житті людей з релігійною свідомістю $є$ не народження, а смерть, то упродовж життя частина людей просто забувала точну дату свого народження $\mathrm{i}$ тому під час переписів округлювала свій вік $[21,57]$. У Тернівці у 1795 р. спостерігалася така тенденція щодо відображення віку населення: 30-річних чоловіків було найбільше серед усіх вікових категорій населення - 23 особи. Причому в найближчих до 30-річних вікових категоріях (від 25 до 35 років) 29, 31, 33 та 34-річних не було жодної особи чоловічої статі і лише по три особи 26 та 28-річних і дві особи 32-річних. А серед осіб жіночої статі найбільшу вікову категорію становили 25-річні (23 особи або 8 \% усього жіноцтва). 
На тлі якісних змін у складі населення локальної території також відбувалися зміни у структурі окремих селянських родин Тернівки. За цими змінами можна відтворити історію родоводу селянських родин. Наприклад, у ревізії 1795 р. родина Лихочасів була записана у складі 40-річного голови родини Василя Петровича Лихочаса, його дружини, 35-річної Агафії Петрівни, та двох синів 15-річного Василя та 6-річного Григорія. Рід занять їх був записаний як «питаются от черной работы» $[17,855]$. Василь Петрович Лихочас у 1811 р. у віці 56 років втік із села (його син Василь втік іще раніше - у 1809 р.) $[18,228]$. У 1812 р. повернувся батько Василь і наступного року помер, а син Василь повернувся лише у 1814 р. Василь Васильович Лихочас одразу після повернення вдруге одружився, а можливо, прибув додому з новою дружиною Устинією, оскільки на час ревізії 1816 р. мав дворічного сина Симеона, записаного як сина від другої дружини, та трьох падчірок - Хавронію 9 років, Агафію 6 років та Катерину 4 років [19, 600 зв.]. Увесь цей час господарством опікувалися 51-річна дружина Лихочаса Агафія та молодший син Василя Петровича Лихочаса Григорій (на момент ревізії 1811 р. йому виповнилося 22 роки). Григорій Лихочас на момент ревізії 1816 р. мав дружину Пелагею (25 років), двох синів Іванів (3 та 1 років) та 5-річну доньку Парасковію. У ревізії 1834 р. родини братів записані окремо під № 1 та № 2. 54-річний Василь Васильович Лихочас мешкав разом зі своїм 20-річним сином Симеоном, дружиною Устинією, двома народженими від Устинії дочками - 16-річною Федосією та 14-річною Агафією та дочкою когось із падчірок (у ревізії записано «Его же второй жены внука Марфа») трирічною Марфою [20, 30 зв. - 31]. Можна лише здогадуватися, яка доля спіткала матір Марфи - чи померла вона, чи втекла, народивши позашлюбну дитину, чи втекла 3 чоловіком, якщо була одружена, полишивши доньку на бабцю Устинію. Родину Григорія Васильовича Лихочаса після смерті батька у 1822 р. (на той час Григорію виповнилося 32 роки) та старшого брата Івана у 1832 р. (на той час Іванові Григоровичу виповнилося 19 років) очолив 19-річний другий син Іван, котрий мав опікуватися двома молодшими братами - 16-річним Ігнатієм та 7-річним Трохимом, а також матір'ю - 43-річною Пелагеєю [20, 30 зв. - 31]. Що сталось із сестрою Івана Парасковією невідомо, але можна сподіватися, що вона одружилася і мешкала в іншій родині.

Записаний у ревізії 1795 р. 65-річний Роман Самійлович Бугера мав статус хлібороба. У нього були 50-річна дружина Настасія Іванівна та 18-річний син Олексій [17, 862 зв.]. Десь у 1800 р. в Олексія народилася донька Варвара. Проте невдовзі Олексій овдовів. Принаймні інші нащадки (народжені у 1808, 1809, 1810 pр. доньки Авдотія, Агафія та син Михайло) були записані в ревізії 1816 р. як діти від другої дружини. У 1816 р. Романові Самійловичу Бугері було 85 років. 
Між цими ревізіями він втратив дружину, тобто був вдівцем. Його син, 38-річний Олексій, уже до цього часу двічі був вдівцем і на 1816 рік був одружений утретє. Від першої дружини у нього була 17-річна донька Варвара, від другої8-річна Авдотія, 7-річна Агафія та 6-річний Михайло, від третьої дружини (34-річної Агафії) - 5-річна Тетяна, 4-річна Домна, 3-річна Авдотія та однорічна Катерина [19, 622 зв. - 623]. У 1818 р. у віці 87 років помирає Роман Самійлович Бугера. В Олексія народжуються між ревізіями ще принаймні дві дочки на час ревізії 1834 р. в нього були 8-річна Марина та 4-річна Зіновія [20, 60 зв. 61]. Між ревізіями з родини зникає Варвара. Можливо, вона вийшла заміж, але привертає увагу незвична для українського села ситуація, коли в родині було багато дорослих дівчат - 26-річна Авдотія, 25-річна Агафія, 23-річна Тетяна, 22-річна Домна, 21-річна Авдотія та 19-річна Катерина, коли в інших родинах в цей час вже набагато молодші дівчата мали чоловіків.

Родина записаного в ревізії 1795 р. під № 6 40-річного Василя Прокоповича Третяка мала такий склад: дружина - 38-річна Авдотія Федорівна, четверо синів (16-річний Іван, 6-річний Яків, 4-річний Федір, 2-річний Матвій), донька (15-річна Парасковія), рідний брат-вдівець (30-річний Ісаак), у якого було троє дітей (7-річна Федосія, 6-річний Григорій, 4-річний Степан) [17, 855 зв.] Ця родина мала тяжку долю. У 1799 р. в 6-річному віці помирає найменший син Василя - Матвій, а 1806 р. - найстарший син Іван. Сам Василь Прокопович Третяк помер 1809 р. У 1806 р. був відданий у міліцію Ісак Прокопович Третяк, найстарший син якого Григорій Ісаакович, напевно, раніше втік $з$ дому, був розшуканий, але залишений за новим власником (у ревізії $\epsilon$ позначка - «залишений за колишнім власником» [18, 229]. На час проведення ревізії 1816 р. головою родини вважався 26-річний Яків Васильович Третяк, який мав 23-річну дружину Ганну та однорічного сина Омеляна. Мати Якова Третяка, напевно, померла між 1800 та 1816 pр., оскільки на час ревізії в родині Якова Третяка рахувалася його молодша сестра 16-річна Парасковія, народжена 1800 р. (старша сестра, також Парасковія, втекла 3 дому 1815 р.). У родині також мешкали неодружені 20-річні брати Якова - рідний брат Федір Васильович та двоюрідний брат Степан Ісаакович $[19,601$ зв. -602]. Куди поділася за цей час Федосія Ісаківна, невідомо. Можливо, вийшла заміж. У ревізії 1834 р. записаний під № 8 44-річний Яків Васильович. Він мав сімох дітей: 19-річного сина Омеляна та шістьох інших дітей, народжених від другої дружини, 37-річної Федосії - 14-річну Авдотію, 13-річного Семена, 12-річного Якова, 8-річну Федосію, 4-річну Параскеву, однорічного Каленика. Його брат, 42-річний Федір Васильович, був записаний в тій самій родині і мав 36-річну дружину Матрону та двох дітей - 12-річного Никифора та однорічну Варвару [20, 31 зв. - 32]. Родина Степана Ісааковича Третяка записа- 
на була вже окремо під № 9 ревізької «сказки». Степан мав дружину, 32-річну Марію, та трьох дітей - 5-річного Федора, 3-річного Льва та однорічну Ганну [20, 32 зв. - 33].

Отже, треба зазначити, що протягом 1795-1834 рр. спостерігалися тенденції щодо зростання соціальної групи власницьких селян Тернівки. Найбільші показники приросту було зафіксовано протягом 1816-1834 pp. На загальну чисельність населення села Тернівки впливало його природне відтворення. Показники смертності поміщицьких селян характеризувалися відносною стабільністю. Статево-вікові піраміди населення Тернівки за 1795 та 1816 рр. дають можливість стверджувати, що демографічна структура власницьких селян була прогресивною, тобто молодь та дорослі кількісно переважали осіб похилого віку. Під час порівняння наведених вище ревізьких «сказок» можна простежити трагічну долю кількох родин, а саме Лихочасів, Третяків, Бугер. Виснажлива праця на землі, незбалансоване харчування, відсутність належного медичного обслуговування та контролю за дітьми призводили до значної кількості смертей серед місцевого населення.

\section{Abstract}

The article is devoted to the study of the genealogy of peasant families in Ternivka (Cherkasy district, Kyiv province). As the main sources for streamlining the ancestry of peasant families were selected auditory "fairy tales» stored in the State Archives of Kyiv region. The article specified the time of creation of auditory «fairy tales» of peasant families in Ternivka (Cherkasy district, Kiev province), the current state of their preservation, the information potential of the documents are revealed. Auditory «fairy tales» helped to establish the dynamics of the number, natural movement, sex-age structure of the peasants of Ternivka for 1795-1834. The history of families (Lyhochas, Tretyak, Bugera), family relationships and relationships were also examined. The main attributes of a person are defined - there're names, surnames, age, place of residence, which appear in the materials of the audit censuses. The author of the study also substantiated the need to use other sources (metric books, confessionals, military accounting materials and kits, etc.) to reconstruct peasant ancestry. Complex information presented in the article will interest museum workers, archivists, amateur historians.

Key words: source analysis, genealogy, audit, audit «fairy tales», Ternivka, Kyiv province.

\section{ДЖЕРЕЛА ТА ЛІТЕРАТУРА}

1. Волошин Ю. В. Статево-вікова та шлюбна структура населення міста Полтави в другій половині XVIII століття. Історична пам'ять. 2011. № 1. С. 5-24.

2. Гедьо А. Матеріали ревізійного перепису населення як джерело з історії іноземних колоністів Донбасу (за матеріалами Державного архіву Донецької області). Наукові записки: Зб. праџь молодих вчених та аспірантів / Інститут украӥнської археографії та джерелознавства ім. М. С. Грушевського НАН Украӥни. Т. 19 (у 2-х кн.). Тематичний випуск «Джерела локальної 
історії: методи дослідження, проблеми інтерпретаиії, популяризація». Кн. І. Київ, 2009. С. 551-562.

3. Дружинина Е. И. Южная Украина в 1800-1825 гг. Москва: Изд-во «Наука», $1970.383 \mathrm{c}$.

4. Історія міст і сіл Української РСР: В 26 т. Черкаська область / ред. кол. тому: Стешенко О. Л. (гол. редкол.), Гольцев С. М., Горкун А. І., Дудник О. М., Зайцев М. С., Звєрєв С. М., Зудіна Г. М., Коваленко В. Я., Кузнецов С. М., Курносов Ю. О., Непийвода Ф. М., Степаненко А. О., Тканко О. В. (заст. гол. редкол.), Храбан Г. Ю., Червінський О. А. (відп. секр. редкол.), Шпак В. Т. АН УРСР. Інститут історії. Київ: Голов. ред. УРЕ АН УРСР, 1972. 788 с.

5. Кабузан В. М. Заселение Новороссии (Екатеринославской и Херсонской губерний) в XVIII - первой половине XIX века (1719-1858 гг.). Москва: Наука, 1976. 308 c.

6. Кабузан В. М. Материалы ревизий как источник по истории населения России XVIII - первой половины XIX в. (1718-1858 гг.). История СССР. 1959. № 5. С. 128-140.

7. Легун Ю., Петренко О. Ревізійний перепис населення 1795 р.: Брацлавська губернія. Ч. 1: Бершадський повіт, т. 1: Ревізійні списки селян сіл: Крикливець, Крушинінка, Лугувате, Любашівка, Ободівка, Поташня, П'ятківка, Рогізка, Татарівка, Христище, Яланець. Вінниця: Консоль, 2003. 284 с.

8. Легун Ю. Генеалогія селян Подільської губернії: джерела. Вінниця: О. Власюк, 2005. $516 \mathrm{c.}$

9. Ликова В. В. Ревізькі сказки як джерело до соціально-економічної історії Південної України першої половини ХІХ ст. (1795-835рp.). Наукові праці історичного факультету Запорізького державного університету. Запоріжжя: Просвіта, 2007. Вип. XXI. С. 345-351.

10. Лобко Н. Теоретичні та практичні питання реконструкції родоводів українців. Спеціальні історичні дисиипліни: питання теорії та методики. Генеалогія та геральдика. 3б. наукових праџь. Київ: НАН України, Інститут історії України, 2012. С. 132-146.

11. Маркова М. Первичные документы по учету населения Санкт-Петербургской губернии в XVIII - первой половины XIX вв. как исторический источник (метрические книги, исповедные росписи, ревизские сказки): дис. канд. ист. наук: спец. 07.00.09. С.-Петербург, 2005. 183 с.

12. Махнова Г. П. Чисельність і склад українського населення Росії в 60-х рр. XVIII ст. Украӥнський історичний журнал. 1965. № 2. С. 111-116.

13. Орлова А. К. вопросу об изучении третьей ревизии. Вестник Ленинградского государственного университета им. А. С. Пушкина. Вып. 3. Т. IV. 2013. C. $71-82$. 
14. Подьяпольская Е. П. Ревизские сказки как исторический источник. Академику Борису Дмитриевичу Грекову ко дню семидесятилетия. Сб. статей / ред. В. П. Волгин и др. Москва: Изд-во Академии Наук СССР, 1952. С. 310-321.

15. Похилевич Л. И. Сказания о населенных местностях Киевской губернии или Статистические, исторические и церковные заметки о всех деревнях, селах, местечках и городах, в пределах губернии находящихся. Біла церква: Вид. О. Пшонківський, 2005. 763 с.

16. Рашин А. Г. Население России за 100 лет (1811-1913 гг.). Статистические очерки / под ред. С. Г. Струмилина. Москва: Гос. стат. изд-во, 1956. 351 с.

17. Ревизская сказка 1795 года, декабря 16, Вознесенского наместничества Черкасского уезда села Тарнавки [Терновки], принадлежащего дедичному владельцу его сиятельству, высокопревосходительному господину, действительному тайному советнику, генерал-прокурору ея императорского величества, действительному камергеру и разных орденов кавалеру графу Александру Николаевичу Самойлову и находящийся в его действительном владении, уполномоченный от него надворный советник и кавалер Андрей Прожика по сим состоявшего 1794 года, июня 23 дня; Ея императорского величества и в народе публикованного указа дал сию сказку о состоящих в упомянутом селе жителях мужеска и женска пола душах не исключая самых малолетних и престарелых по самой истине без всякой утайки и будь кем впредь обличен явлюсь и по сей действительному найдется что кого либо утаил то по вине положенному по указам и штрафу без всякого послабления. Державний архів Київської області. Ф. 280. Київська казенна палата. Оп. 2. Спр. 63. Арк. 855-864 зв.

18. Ревизская сказка 1811 г. сентября 23 дня, Киевской губернии Черкасского уезда помещика села Терновки помещика генерал-майора Крестьяна Крестьяновича Гревса о состоящих мужеска пола дворовых людях и крестьянах. Державний архів Київської області. Ф. 280. Київська казенна палата. Оп. 2. Спр. 286. Арк. 228-249 зв.

19. Ревизская сказка 1816 г. марта 10 дня, Киевской губернии Черкасского повета помещика генерал-майора и кавалера Крестьян Крестьяновича Гревса селения Терновка, о состоящих мужского женского пола дворовых людях и крестьянах. Державний архів Київської області. Ф. 280. Київська казенна палата. Оп. 2. Спр. 369. Арк. 598-626.

20. Ревизская сказка 1834 года, апреля 12 дня, Киевской губернии Черкасского уезда села Терновки, помещиков отставного подпоручика Александра и гвардии и штаб капитана Владислава Крестьяновых Гревсов состоящих мужеска и женска пола дворовых людях и крестьян. Державний архів Київської області. Ф. 280. Київська казенна палата. Оп. 2. Спр. 687. Арк. 28-72. 
21. Сердюк І. О. Особливості відображення вікових категорій населення Лівобережної України в Рум'янцевському описі Малоросії. Вісник Черкаського університету. Серія «Історичні науки». 2008. № 33-34. С. 55-62.

22. Троицкая И. Ревизии населения России как источник демографической информации (методологические проблемы): дис. ... канд. экон. наук: спец. 08.00.18. Москва, 1995. 123 с.

\section{References}

1. Voloshyn, Yu. V. (2011). Statevo-vikova ta shliubna struktura naselennia mista Poltavy v druhii polovyni XVIII stolittia [Sex-age and marriage structure of the population of Poltava in the second half of the XVIII century]. Istorychna pamiat, № 1.

2. Hedo, A. (2009). Materialy reviziinoho perepysu naselennia yak dzherelo z istorii inozemnykh kolonistiv Donbasu (za materialamy Derzhavnoho arkhivu Donetskoi oblasti) [Materials of the population census as a source from the history of foreign colonists of Donbass (based on materials of the State archive of Donetsk region] (2009). Naukovi zapysky, T. 19. Kn. I.

3. Druzhynyna, E. Y. (1970). Yuzhnaia Ukraina v 1800-1825 hh. [Southern Ukraine in 1800-1825]. Moskva: Nauka.

4. Istoriia mist i sil Ukrainskoi RSR: V 26 t. Cherkaska oblast [History of cities and villages of the Ukrainian SSR: In 26 vol. Cherkasy region] (1972). AN URSR. Instytut istorii. Kyiv: Holov. red. URE AN URSR.

5. Kabuzan, V. M. (1976). Zaselenie Novorossii (Ekaterinoslavskoi i Khersonskoi hubernii) v XVIII - pervoi polovine XIX veka (1719-1858 hh.) [Settlement of Novorossiya (Yekaterinoslav and Kherson provinces) in the 18th - first half of the 19th century (1719-1858)]. Moskva: Nauka.

6. Kabuzan, V. M. (1959). Materialy revizii kak istochnik po istorii naseleniia Rossii XVIII - pervoi poloviny XIX v. (1718-1858 hh.) [Materials of revisions as a source on the history of the population of Russia in the XVIII - first half of the 19th century (1718-1858)]. Istoriia SSSR, № 5.

7. Lehun, Yu., Petrenko, O. (2003). Reviziinyi perepys naselennia 1795 r.: Bratslavska huberniia. Ch. 1: Bershadskyi povit, t. 1: Reviziini spysky selian sil: Kryklyvets, Krushyninka, Luhuvate, Liubashivka, Obodivka, Potashnia, Piatkivka, Rohizka, Tatarivka, Khrystyshche, Yalanets [Auditory Census of 1795: Bratslav province. Part 1: Bershad district, Volume 1: Audit lists of peasants of villages: Kryklyvets, Krushyninka, Luguvate, Lyubashivka, Obodivka, Potashna, Pyatkovka, Rogozhka, Tatarivka, Baptism, Yalanets]. Vinnytsia: Konsol.

8. Lehun, Yu. (2005). Henealohiia selian Podilskoi hubernii: dzherela [Genealogy of the peasants of Podolsk province: sources]. Vinnytsia: O. Vlasiuk. 
9. Lykova, V. V. (2007). Revizki skazky yak dzherelo do sotsialno-ekonomichnoi istorii Pivdennoi Ukrainy pershoi polovyny XIX st. (1795-1835 rr.) [Auditory fairy tales as a source for the socioeconomic history of southern Ukraine in the first half of the 19th century (1795-1835)]. Naukovi pratsi istorychnoho fakultetu Zaporizkoho derzhavnoho universytetu, vyp. XXI.

10. Lobko, N. (2012). Teoretychni ta praktychni pytannia rekonstruktsii rodovodiv ukraintsiv [Theoretical and practical issues of reconstruction of the pedigrees of the Ukrainians]. Spetsialni istorychni dystsypliny: pytannia teorii ta metodyky. Henealohiia ta heraldyka. Kyiv: NAN Ukrainy, Instytut istorii Ukrainy.

11. Markova, M. (2005). Pervichnyie dokumenty po uchetu naselenyia Sankt-Peterburhskoi hubernyy v XVIII - pervoi poloviny XIX vv. kak istoricheskii istochnyk (metricheskiie knihi, ispovednyie rospysy, revyzskiie skazki) [Primary documents for the accounting of the population of St. Petersburg province in the 18th-first half of the 19th century. as a historical source (metric books, confessions, audits)]: dys. kand. ist. nauk. S-Pb.

12. Makhnova, H. P. (1965). Chyselnist i sklad ukrainskoho naselennia Rosii v 60-kh rr. XVIII st. [The size and composition of the Ukrainian population of Russia in the 60 's of the 18th century]. Ukrainskyi istorychnyi zhurnal, № 2.

13. Orlova, A. (2013). K voprosu ob izuchenii tretiei revizii [On the question of the study of the third revision]. Vestnik Lenynhradskoho hosudarstvennoho unyversyteta ym. A. S. Pushkyna, vyp. 3. T. IV.

14. Podiapolskaia, E. P. (1952). Revyzskie skazki kak istoricheskii istochnik [Revize fairy tales as a historical source]. Akademyku Borysu Dmytryevychu Hrekovu ko dniu semydesiatyletyia. Moskva: Yzd-vo Akademyy Nauk SSSR.

15. Pokhylevych, L. Y. (2005). Skazanyia o naselennykh mestnostiakh Kyevskoi hubernii ili Statystycheskie, istorycheskie i tserkovnyie zametki o vsekh derevniakh, selakh, mestechkakh i horodakh, v predelakh hubernii nakhodiashchykhsia [Collected stories about populated areas of the Kiev province or Statistical, historical and church notes on all villages, villages, towns and cities within the province]. Bila Tserkva: Vydavets Oleksandr Pshonkivskyi.

16. Rashyn, A. H. Naseleniie Rossii za 100 let (1811-1913 hh.). Statisticheskiie ocherki (1956). [Population of Russia for 100 years (1811-1913). Statistical essays]. Moskva : Hosudarstvennoe statisticheskoie izdatelstvo.

17. Revizskaia skazka 1795 hoda, dekabria 16, Voznesenskoho namestnichestva Cherksasskoho uezda sela Tarnavki [Ternovki] prynadlezhashcheho dedychnomu vladeltsu eho siiatelstvu, vysokoprevoskhodytelnomu hospodinu, deistvytelnomu tainomu sovetniku, heneral-prokuroru eia imperatorskoho velichestva, deistvitelnomu kamerheru i raznykh ordenov kavaleru hrafu Aleksandru Nikolaevichu 
Samoilovu i nakhodiashchyisia v eho deistvitelnom vladeniyi, upolnomochennyi ot neho nadvornyi sovetnyk i kavaler Andrei Prozhyka po sim sostoiavsheho 1794 hoda, iyunia 23 dnia; Eia imperatorskoho velichestva i v narode publikovannoho ukaza dal siiu skazku o sostoiashchikh v upomianutom sele zhyteliakh muzheska i zhenska pola dushakh ne iskliuchaia samykh maloletnikh i prestarelykh po samoi istine bez vsiakoi utaiki i bud-kem vpred oblichen iavlius i po sei deistvitelnomu naidetsia chto koho-libo utail to po vine polozhennomu po ukazam i shtrafu bez vsiakoho poslablenyia [Revision story of 1795, December 16, of the Ascension of the ascension of the Cherksas district of the village of Tarnavki [Ternovki] belonging to his grandfather's grandfather, his high-ranking gentleman, a real secret advisor, a prosecutor-general of her imperial chieftain, Alexander in his actual possession, the weather advisor and cavalry officer Andrei Prozhik, who was authorized by him, dated 1794, June 23; Her imperial majesty and in the people of the published decree gave this fairy tale about the male and female souls in the mentioned village residents, not excluding the youngest and the elderly in the truth without any sludge, and whether anyone will continue to be imprisoned and to this one there will be something or someone the fault laid down by the decrees and the fine without any weakening]. Derzhavnyi arkhiv Kyivskoi oblasti. F. 280. Kyivska kazenna palata. Op. 2. Spr. 63.

18. Revizskaia skazka 1811 h. sentiabria 23 dnia, Kyevskoi hubernii Cherksasskoho uezda pomeshchika sela Ternovki pomeshchika heneral-maiora Krestian Krestianovicha Hrevsa o sostoiashchikh muzheska pola dvorovykh liudiakh i krestianakh [Revision fairy tale 1811 September 23, Kiev province Cherkasy county landowner of the village of Ternovki landlord Major General Krestyan Krestyanovich Grevs about men of the courtyards and peasants]. Derzhavnyi arkhiv Kyivskoi oblasti. F. 280. Kyivska kazenna palata. Op. 2. Spr. 286.

19. Revizskaia skazka 1816 h. marta 10 dnia, Kyevskoi hubernyy Cherkasskaia poveta pomeshchika heneral maiora y kavalera Krestian Krestianovicha Hrevsa seleniyia Ternovka, o sostoiashchikh muzhskoho zhenskoho pola dvorovykh liudiakh y krestianakh [The revision tale of March 1816, on the 10th day of the Kiev province, Cherkasy Povet landowner, Major General and Chevalier Krestyan Krestyanovich Grevs of the village of Ternovka, about male and female courtyards and peasants]. Derzhavnyi arkhiv Kyivskoi oblasti. F. 280. Kyivska kazenna palata. Op. 2. Spr. 369.

20. Revizskaia skazka 1834 hoda, aprelia 12 dnia, Kyevskoi hubernii Cherkasskoho uezda sela Ternovki, pomeshchikov otstavnoho podporuchika Aleksandra i hvardii i shtab-kapitana Vladyslava Krestianovikh Hrevsov sostoiashchikh muzheska i zhenska pola dvorovykh liudiakh i krestian [The revision tale of 1834, April 12, 
in the Kiev province of Cherkasy county of Ternovka village, the landowners of retired second lieutenant Alexander and the guard and the headquarters of captain Vladislav Krestyanovs Grevs consisting of men and women of the yard people and peasants]. Derzhavnyi arkhiv Kyivskoi oblasti. F. 280. Kyivska kazenna palata. Op. 2. Spr. 687.

21. Serdiuk, I. O. (2008). Osoblyvosti vidobrazhennia vikovykh katehorii naselennia Livoberezhnoi Ukrainy v Rumiantsevskomu opysi Malorosii [Peculiarities of the image of the age-old population category of the Liberated Ukraine in the Rumyantsevsky description Serdyuk]. Visnyk Cherkaskoho universytetu. Seriia «Istorychni nauky», № 33-34.

22. Troytskaia, Y. (1995). Revizii naseleniia Rossii kak istochnik demohraficheskoi informatsii (metodolohicheskiye problemy) [Revision of the population of Russia as a source of demographic information (methodological problems)]: dys. kand. ekon. nauk. Moskva.

УДК 94:669-057.21](477.7) «18» (092)

\section{РОЛЬ ІНЖЕНЕРНО-ТЕХНІЧНОЇ ІНТЕЛІГЕНЦІЇ В СТАНОВЛЕННІ ТА РОЗВИТКУ ПРОМИСЛОВОСТІ ПІВДНЯ УКРАЇНИ МОДЕРНОЇ ДОБИ}

\section{Довжук Ігор}

Мета статті - розглянути професійну діяльність гірничих інженерів та інших профільних фахівиів на Півдні Украӥни в модерну добу та показати їхню роль у становленні й розвитку тут металургійної промисловості.

Видатний гірничий інженер А. Ф. Мевіус присвятив майже півстоліття свого життя розвитку металургії Донечького басейну. Він багато років пропрацював у Луганському гірничому окрузі, начальником якого був з 1861 р. Працюючи на цій посадi, він зробив багато корисного для розвитку гірничо-металургійного виробництва в Донбасі. У 1860-ті роки керував будівництвом периої в Украӥні пудлінгової фабрики Луганського ливарного заводу. А. Ф. Мевіус - один з ініціаторів скликання з '̈здів гірничопромисловців Півдня Росії, які відіграли провідну роль у створенні промисловості Донбасу і Придніпров'я. Протягом 20 років він керував виконавчим органом з '̈здів - иого радою, користуючись авторитетом серед гірничих спеціалістів і промисловців Півдня.

Інженерно-технічна інтелігенція відіграла значну роль у становленні та розвитку залізорудної і металургійної промисловості Півдня у перед- $і$ післяреформений період. Інженери $i$ техніки спрямовували свою діяльність на вдосконалення виробництва та вивчення надр промислового регіону України. Відкриті інженерами великі поклади залізних руд стали базою для бурхливого розвитку тут металургійної промисловості. Технічні нововведення, упроваджені за ініціативою інженерно-технічних працівників, сприяли зростанню продуктивності виробництва. Окрім виробничої діяльності інженери займалися науковими дослідженнями, 